\title{
Sankcioniranje malih i srednjih poduzeća za neispunjavanje poreznih obveza
}

Swistak, Artur

Source / Izvornik: Odabrani prijevodi, 2016, 7, 1 - 17

Journal article, Published version

Rad u časopisu, Objavljena verzija rada (izdavačev PDF)

https://doi.org/10.3326/op.36

Permanent link / Trajna poveznica: https://urn.nsk.hr/urn:nbn:hr:242:334132

Rights / Prava: Attribution-NonCommercial-NoDerivatives 4.0 International/ImenovanjeNekomercijalno-Bez prerada 4.0 međunarodna

Download date / Datum preuzimanja: 2023-04-26

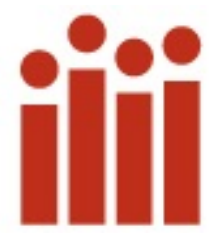

Institute of Public Finance Repository

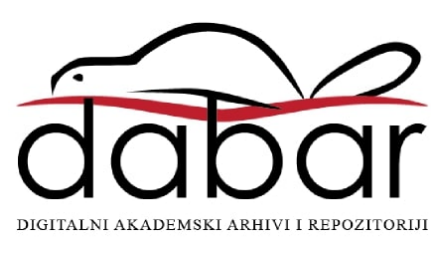


Institut za

javne financije

Smičiklasova 2I | Zagreb

www.ijf.hr | ured@ijf.hr

T: oI/4886-444 | F: OI/48I9-365

\section{ODABRANI}

\section{PRIJEVODI}

\section{BR. 36}

\section{6.}

ISSN I847-7445

citirati: Swistak, A. 20I6. Tax penalties in SME tax compliance. Financial Theory and Practice, 40 (I), str. I29-I47. Dostupno na: 〈http:/ /www.fintp.hr/upload/files/ftp/20I6/I/swistak.pdf.

Svi Odabrani prijevodi dostupni su na: http://www.ijf.hr/hr/publikacije/ca sopisi/ı2/odabrani-prijevodi/III

\section{SANKCIONIRANJE MALIH I SREDNJIH PODUZEĆA ZA NEISPUNJAVANJE POREZNIH OBVEZA}

M.A.ARTUR SWISTAK, DOKTORSKI KANDIDAT ${ }^{*}$

\author{
PREGLEDNI ČLANAK ${ }^{* *}$ \\ JEL: H26, H32, H83, K42 \\ DOI: $10.3326 /$ op. 36
}

\section{SAŽETAK}

Problematika ispunjavanja poreznih obveza malih poduzeća zahtijeva posebnu pozornost. S jedne strane, mala su poduzeća osjetljivija na vanjske rizike, često nisu sposobna striktno poštivati i ispunjavati svoje porezne obveze te nastoje iskoristiti prilike da ih uopće ne ispune. $S$ druge strane, za razliku od velikih, kada se govori o malim poduzećima obično se radi o poduzećima s jednim vlasnikom (eng. sole proprietor) ili poduzećima kojima upravljaju sami vlasnici (eng. owner-operated businesses), zbog čega su u velikoj mjeri osjetljiva na osobne, socijalne, kognitivne i emocionalne čimbenike. Ova obilježja utiru put ka kvalitetnoj uporabi mjera namijenih utjecaju na njihovo ponašanje i izbore. U radu se govori o ulozi $i$ učinkovitosti poreznih sankcija (kazni) u cilju povećanja stupnja ispunjavanja poreznih obveza u malim poduzećima. Tordi se da, unatoč nužnosti njihova postojanja u provođenju poreznih zakona, porezne sankcije, kao instrument osiguranja ispunjavanja porezne obveze, ne bi trebale predstavljati prvi izbor. Prestrog porezni režim koji je previše orijentiran na sankcije značajna je prepreka tzv. formalizaciji poslovanja poduzeća (eng. business formalization)' ${ }^{x}$ a sve strože i veće porezne sankcije ne daju željene rezultate. Kako bi bile učinkovite, porezne bi sankcije umjesto represivnosti obveznike trebale odvratitiod nepoštivanja poreznih obveza i potaknuti ih na njihovo ispunjavanje.

Ključne riječi: porezne sankcije, provedba zakonskih odredbi o oporezivanju, ispunjavanje poreznih obveza MSP-a, oporezivanje MSP-a

*Autor se zahvaljuje Johnu Norregaardu i Enrique Rojasu (obojica iz MMF-a) te dvojici anonimnih recenzenata na korisnim komentarima. Sve pogreške i propusti isključiva su odgovornost autora.

Ranija verzija ovog teksta predstavljena je na regionalnoj konferenciji: Izazovi ispunjavanja poreznih obveza malih i srednjih poduzeća koju je 20. i 21. rujna 2012. organizirala Svjetska banka u

Sankt Petersburgu, Rusija.

"Primljeno: 25. rujna 2015.

Prihvaćeno: 1O. studenog 2015.

Artur SWISTAK

Sveučilište u Varšavi, Ekonomski fakultet, Niepodległości I62, 02-554, Varšava, Poljska e-mail: artur.swistak2@gmail.com.

${ }^{\text {I }}$ Eng. "business formalization" može se prevesti kao: registriranje prethodno neprijavljenih tj. neregistriranih djelatnosti/tvrtki; registriranje djelatnosti koje su prethodno obavljane "na crno"; te transformacija poslovanja iz neslužbenog u službeno gospodarstvo (op. prev.). 


\section{UVOD}

Mala su i srednja poduzeća (MSP, eng. SME) u svakoj zemlji važan dio ukupne populacije poreznih obveznika, a njihovo je oporezivanje uobičajeno veoma izazovan proces. Unatoč brojnosti, značaj je MSP-a u smislu doprinosa državnim blagajnama relativno mali, dok porezne administracije često na njihovo administriranje potroše znatna, ionako oskudna, sredstva koja su potrebnija negdje drugdje u administriranju poreznog sustava. Osim toga, MSP karakteriziraju niske razine ispunjavanja poreznih obveza, posebice kod samozaposlenih, što nadalje smanjuje potencijalne porezne prihode i povećava napore poreznih administracija (Engelshalk, 2004.; OECD, 2009.; OECD, 2O14.). Mnoge zemlje rješenje ovih pitanja vide u pojednostavljenju poreznog režima za MSP-e i osmišljavanju i primjeni namjenskih strategija ispunjavanja poreznih obveza (IFC, 2007.; OECD, 2009.; Crawford i Freedman, 2010.). Temeljni je cilj kvalitetno osmišljenog pojednostavljenog poreznog režima povećanje učinkovitosti oporezivanja malih poduzeća, i to smanjenjem troškova oporezivanja i napora poreznih administracija, dok strategije povećanja stupnja ispunjenja poreznih obveza (eng. compliance-enhancing strategies) imaju za cilj uključivanje i učinkovitiju uporabu različitih administrativnih instrumenata koji omogućuju što veći obuhvat obveznika u poreznu mrežu, potiču (ohrabruju) postojeće obveznike da dobrovoljno ispune svoje porezne obveze te u konačnici stvaraju široko raširenu kulturu plaćanja poreza.

Cijeli je niz mjera koje se mogu uporabiti za povećanje razine ispunjavanja poreznih obveza. Primjerice, pretpostavljeni porez (eng. presumptive taxation - porez na prosječnu, a ne na stvarnu osnovicu, op. prev.), manji teret poreznih obveza, uključujući i smanjenje učestalosti ispunjavanja poreznih prijava i plaćanja poreza, uporaba informacija treće strane, IT rješenja te otvorena komunikacija s obveznicima samo su neke od mogućih mjera (Thuronyi, 1998., Chen i sur., 2002.; Engstom i sur., 2006.; OECD, 2009.; OECD, 2010.; Swistak, 2015.). Porezne sankcije imaju ulogu zastrašivanja i odvraćanja od takvog postupanja te poticanja i ispravljanja nepravilnog ponašanja obveznika (Wenzel, 2004.; OECD, 2010.; Poppelwell, 2012.).

Ako se provodi sama za sebe, niti jedna od ovih mjera ne daje zadovoljavajuće rezultate i učinkovitije su kada se koriste uz dodatne instrumente. Porezne sankcije mogu biti, a obično to i jesu, vrlo važan dio ovakve kombinacije (Devos, 2004., Popplewell i sur., 2012.). One mogu itekako snažno utjecati na ponašanje poreznih obveznika, ali ih nikada ne bi trebalo smatrati primarnim ili jedinim instrumentom (Tyler, 2006.; OECD, 2010.). Matthews (2005.) ističe kako je mit o sankcioniranju odavno razbijen. Porezne sankcije mogu biti učinkovitije koriste li se kao pomoćno sredstvo osmišljavanja i provedbe ispravne strategije ispunjavanja obveza. Upravo stoga važno je da kreatori politika i porezni službenici dobro razumiju samu prirodu poreznih sankcija. U suprotnome bi zanemarivanje njihovih posljedica i učinaka te prekomjerno korištenje poreznih kazni moglo postati uobičajeno.

No, sveukupna kvaliteta oporezivanja i općenito ponašanje poreznih obveznika ne ovise samo o zastupljenosti tradicionalnih vrsti poreznih sankcija. Naime, određena obilježja poreza i postupci porezne administracije mogu također za porezne obveznike predstavljati svojevrsni oblik sankcija. Zbog toga su ta obilježja i postupci administracije važan dio rasprave o poreznim sankcijama ili, $\mathrm{u}$ najširem smislu, restriktivne prirode poreznog sustava (Wenzel, 2004.; Kirchler i sur., 2007;; OECD, 20IO.).

Zbog svega ovoga potrebno je odgovoriti na sljedeća važna pitanja: zahtijeva li ispunjavanje poreznih obveza u malim poduzećima posebnu pozornost? Ako je odgovor pozitivan, kolika je važnost poreznih 
sankcija u snaženju i provedbi takvih politika? Na koje načine one utječu na ponašanje poreznih obveznika? U kojoj mjeri mogu utjecati na razmjere neslužbenog gospodarstva? I u kojoj mjeri trebaju biti kažnjavajući i strogi porezni propisi?

U članku se daje kratak pregled uloge poreznih sankcija prilikom ispunjavanja poreznih obveza u malim tvrtkama i nastoji odgovoriti na gore navedena pitanja. Na početku se govori o mogućnostima poreznih sankcija kao vodilje za ispunjavanje poreznih obveze u MSP-ima. Nakon toga govori se o njihovim ciljevima i oblicima, iza čega slijedi kratko izlaganje o težini poreznih kazni i alternativama u njihovoj uporabi. Posljednje poglavlje donosi zaključna razmišljanja, kao i nekoliko praktičnih smjernica za učinkovito korištenje poreznih kazni.

\section{ZAŠTO SU KAZNE UOPĆE VAŽNE PRILIKOM OPOREZIVANJA MALIH I SREDNJIH PODUZEĆA?}

Oporezivanje malih i srednjih poduzeća postavlja drugačije izazove od oporezivanja velikih poduzeća. Postoji nekoliko razloga zašto su prilikom ispunjavanja poreznih obveza važne veličina i struktura poduzeća.

Malim poduzećima, a u većini slučajeva radi se o poduzećima $s$ jednim vlasnikom ili dioničkim društvima kojima upravlja sam vlasnik, često nedostaju dostatni kapaciteti da valjano ispune svoje porezne obveze, pogotovo ako su one velike (Evans i sur., 2005.; Engstrøm i sur., 2006.). Samo si manji broj malih poduzetnika može ili želi priuštiti korištenje profesionalnih poreznih servisa i umjesto toga se oslanjaju sami na sebe. Međutim, niska razina svijesti o poreznim obvezama², uz relativno sporiju prilagodbu na promjene poreznih zakona, često dovode do pogrešaka i kašnjenja u izračunu, izvješćivanju i, u konačnici, u plaćanju poreznih obveza (McKerchar, 1995.; Coleman i Freeman, 1997.). Rizik od nenamjernog neispunjavanja obveza dodatno je povećan zbog osjetljivosti malih poduzeća na promjene tržišnih uvjeta. Svako izlaganje trgovinskim šokovima (npr. privremena zabrana izvoza) ili kašnjenje u plaćanju za isporučena dobra i usluge (npr. kašnjenja u plaćanjima izvođača radova kooperantima/podizvođačima) lako može dovesti do privremene nelikvidnosti (Kitching, 20II.; Ogawa i sur., 2012.). S obzirom da, za razliku od velikih, mala poduzeća imaju ograničene mogućnosti osiguranja dodatnih izvora sredstava, npr. dostupnost bankovnih kredita, ona često nisu u mogućnosti promptno platiti svoje poreze (Ayadi i Gadi, 2013.; Darvas, 2013.; ECB, 2013.; Ozturk i Mrkaic, 2014.).

S druge strane, namjerno neispunjavanje poreznih obveza također je učestalije kod malih poduzeća (Cowell, 2003.; Slemrod, 2004.; Crocker i Slemrod, 2005.). Brojnim MSP-ima, čak i ako je riječ o dioničkim društvima, upravljaju vlasnici. Za razliku od profesionalnih menadžera ili računovođa u velikim tvrtkama, oni posluju s vlastitim kapitalom i imaju različite interese prilikom njegova korištenja. Izravnim povećanjem dobitaka od nezakonitog izbjegavanja plaćanja poreza, tj. utaje poreza, osobna nesklonost riziku managera (direktora) koji su ujedno i vlasnici poduzeća može biti niža. Sukladno tome, oni su osjetljiviji na promjene financijske situacije i nepravedno postupanje porezne administracije, ili su jednostavno u iskušenju od iskorištavanja mogućnosti koje im stoje na raspolaganju. Neupitno je kako mala poduzeća imaju više prilika za neispunjavanje poreznih obveza od velikih - mogu koristiti novčane transakcije, prikriti svoju osobnu potrošnju u obliku ulaznih računa poduzeća (eng. business input) ili sakriti stvarne isplate plaća (Cowell, 2003.; Engstrøm i sur., 2006.). Na

${ }^{2}$ Odgovorne osobe u malim poduzećima često ne razumiju određene porezne obveze te osnovnu svrhu i prirodu poreza. PDV je klasični primjer za to. Mala poduzeća PDV često doživljavaju kao porez na ostvarenu dobit, umjesto kao porez na finalnu potrošnju. Bez detaljnog poznavanja mehanizma PDV-a oni mogu biti skloniji izbjegavanju registriranja za potrebe PDV-a, čak i ako bi to za njih bilo korisno. "Skrivajući" se iza praga za registraciju za potrebe PDV-a, takva poduzeća postaju porezni utajivači - prikrivanjem traga računa - te daju i ostalim poduzećima prilike za neispunjavanje poreznih obveza. 
taj način manipuliraju svojom prodajom, maržama, dobiti, čak i isplaćenim oporezovanim plaćama zaposlenika. Što je još važnije, njima je puno lakše ako uopće nisu službeno registrirana. Posebne porezne olakšice koje mala poduzeća mogu koristiti otvaraju i druge mogućnosti za porezne zlouporabe, npr. skrivanjem ispod prihvatljivog praga pretpostavljenog poreza (OECD, 2009.).

Osim kazni zbog neispunjavanja poreznih obveza, postoje i drugi rizici koji utječu na mala poduzeća. Za razliku od velikih, mala su poduzeća izložena i zlostavljanju i tlačenju od strane samih poreznih administracija (npr. pretjerane revizije, duge i otežavajuće porezne procedure i postupci, neopravdani zahtjevi za certifikacijama, korupcija). Iako strogo gledajući ne predstavljaju poreznu sankciju, takvi postupci predstavljaju svojevrsnu kaznu u širem smislu, koja može imati negativan utjecaj na ispunjavanje porezne obveze (McClellan, 2013.).

Struktura poreznog sustava također je važan čimbenik u procesu. Preteške porezne obveze, višestruki porezi, visoke porezne stope i sveukupna složenost poreznih zakona malim su poduzećima velik izazov. Čak i ako dođe do uvođenja nekih posebnih ustupaka (npr. rjeđe ispunjavanje obveza i plaćanje poreza, računovodstvo novčanog tijeka ili pretpostavljeno oporezivanje), nisu uklonjeni svi rizici. Kako su neke mjere uvjetne (npr. samo za dobrostojeće porezne obveznike) i ograničene (npr. prag prometa, ograničenja prilikom zapošljavanja, isključivanje posebnih aktivnosti), potrebno je, uz postojeće rizike zlouporaba, stalno promatrati i kriterije podobnosti (Thuronyi, 1998.; IFC, 2007.; OECD, 2009.).

Već je rečeno kako postoje brojni rizici od neispunjavanja poreznih obveza. U isto su vrijeme mala poduzeća, zbog veličine i osobnih obilježja, osjetljivija na poticaje za ispravljanjem svoga postupanja od velikih poduzeća, što upućuje na zaključak kako su u slučaju malih poduzeća mjere usmjerene na promjenu ponašanja, uključujući i porezne kazne, od velike važnosti za povećanje poštivanja i ispunjavanja poreznih obveza.

\section{POREZNE KAZNE KAO POTIGAJ ZA ISPUNJAVANJE POREZNIH OBVEZA}

\section{I. EKONOMSKI MODEL ODVRAĆANJA I ZASTRAŠIVANJA}

Čini se kako se porezne administracije u mnogim zemljama oslanjanju na pojačane kontrole i težinu kazni kao glavne instrumente poštivanja poreznih propisa. Uvjerenje u učinkovitost takvog pristupa potječe još od tzv. ekonomskog modela odvraćanja i zastrašivanja kojega su 1972. razvili M. Allingham i A. Sandmo.

Ovaj model pretpostavlja kako racionalni porezni obveznici odluke temelje isključivo na ekonomskom izračunu. Ako obveznici smatraju da su troškovi utaje poreza veći od možebitnih koristi od takvog postupanja, tada će poštivati i ispuniti svoje porezne obveze. Ako su, pak, očekivani troškovi nezakonitog izbjegavanja plaćanja poreznih obveza niži od očekivanih koristi, obveznici nemaju poticaj ispuniti svoje obveze. Zbog toga je u cilju ograničavanja utaje poreza dovoljno samo češće provjeravati porezne obveznike i uvesti strože kazne. Čini se kako je ovakav pristup, u svojoj jednostavnosti, izuzetno uvjerljiv. Međutim, problem je što niti jedna porezna administracija nema dovoljnih kapaciteta da često provjerava sve porezne obveznike i nameće strože kazne. Te činjenice racionalni porezni obveznici mogu kvalitetno ugraditi u svoje izračune i odlučiti nastaviti s poreznom utajom. Osim toga, praksa baš i ne potvrđuje teoriju, jer mnogo je manje poreznih utaja nego to ovaj model pretpostavlja. Drugi, pak, čimbenici, poput socioloških i psiholoških, određuju stvarne razine ispunjavanja poreznih obveza.

Zbog toga bi, umjesto oslanjanja na klasične modele odvraćanja i zastrašivanja, porezne administracije trebalo primorati da bolje razumiju ponašanje obveznika i omoguće poticaje za snažnije ispunjavanje 
poreznih obveza. To ne znači da porezne kazne više nisu važne. One su još uvijek potrebne, ali ih treba koristiti strateški i nadopuniti s drugim mjerama i akcijama.

Porezne su kazne samo jedan od brojnih čimbenika koji potiču obveznika na ispunjavanje poreznih obveza. Drugi čimbenici uključuju nesklonost riziku, osobne i društvene norme i pravila ponašanja, prilike, poštenje i povjerenje te ekonomske čimbenike (OECD, 2OIO.). Zbog svega toga se oslanjanje isključivo na porezne kazne nije pokazalo učinkovitim. Za postizanje najboljih rezultata ključno je poznavati ponašanje poreznih obveznika, što je iznimno složeno. Kao što je izuzetno složen i odnos između poreznih kazni i ispunjavanja poreznih obveza (OECD 20Io., Popplewell i sur., 2012.).

\subsection{DOBROVOLJNO NASUPROT PRISILNOG ISPUNJAVANJA POREZNE OBVEZE}

Nužno je razlikovati prisilno i dobrovoljno ispunjavanje porezne obveze. Porezne kazne, po svoj prilici, ne potiču obveznike koji su ionako spremni poštivati i ispuniti svoju poreznu obvezu. U biti, ako se dogodi da obveznici budu nepravedno kažnjeni u tome ih se može i obeshrabriti. No, niti obveznici koji dobrovoljno odluče ne ispunjavati svoje porezne obveze nisu homogena skupina - neki od njih varaju samo ponekad, neki to iskorištavanjem postojećih mogućnosti čine redovito, dok neki prilikom ispunjavanja poreznih obveza varaju stalno. U idealnom bi slučaju s takvima obveznicima trebalo drugačije postupati.

Kako bi se unaprijedio proces dobrovoljnog ispunjavanja poreznih obveza i poštivanje poreznih zakona nužno su potrebne raznovrsne strategije i pristupi. Poboljšanje poslovne klime i plaćanja poreza ne zahtijeva puko oslanjanje na porezne sankcije budući da bi i bez toga bilo teško raditi na otkrivenim slučajevima poreznih prekršaja. Vjerojatnije je kako bi bolje rezultate dalo uklanjanje prekomjernih poreznih obveza, modernizacija, pojednostavljenje procesa i povećanje učinkovitosti porezne administracije te podrška i povjerenje.

Već je ranije spomenuto kako je odnos između poreznih kazni i poreznih obveza veoma složen. Porezne kazne mogu imati i pozitivan i negativan utjecaj na porezne obveznike. Ako su pravedne i prihvatljive, tada utječu na porast ispunjavanja poreznih obveza. No, ako ih obveznici smatraju pretjeranim i ugnjetavačkim, vjerojatno će stvoriti otpor i rezultirati još većim neispunjavanjem poreznih obveza.

Također je važan i učinak zastrašivanja i odvraćanja obveznika. Pri tome na ovo pitanje ne odgovaraju svi porezni obveznici na identičan način. Nedavna su OECD-ova istraživanja (2010., 2012.) pokazala kako veći učinak zastrašivanja i odvraćanja porezne kazne imaju na porezne obveznike koji rizik i težinu kazne smatraju visokim, nisu vođeni moralnom obvezom ispunjavanja obveze, koji primijete kako su društveni troškovi neispunjavanja poreznih obveza visoki te se osvjedoče kako obveznici koji ne ispunjavaju porezne obveze bivaju uhvaćeni i kažnjeni. Sve to naglašava činjenicu kako je ključan izazov razumjeti osobne karakteristike poreznih obveznika i obrasce ponašanja. Također je potrebno imati i jaku i pouzdanu poreznu administraciju koja na učinkovit način stvara osjećaj neophodnosti i pravednosti poreznih sankcija. Moral se poreznih obveznika naruši ako primijete da nekažnjeno prođu oni koji ne ispunjavaju svoje obveze. Upravo stoga važno je sankcionirati obveznike koji izbjegavaju ispunjavanje svojih poreznih obveza, i to ne samo kako bi ih se u prvom redu odvratilo od takvog postupanja i motiviralo za ispunjavanjem obveza, nego i kako bi se javnosti prenijela poruka o neprihvatljivosti takvog ponašanja. Učinkovitost poreznih administracija na tome polju gradi 
međusobno povjerenje i stvara veoma važnu društvenu normu kako je plaćanje poreza ispravna stvar koju treba napraviti.

Hvatanje u koštac s iskusnim poreznim prekršiteljima i prevarantima zahtijeva, pak, malo drugačiji pristup. Otkrivanje i kažnjavanje jednog poreznog kaznenog djela može stvoriti iluziju sigurnosti, jer takvi porezni obveznici mogu povjerovati kako je nemoguće da ih se dva puta na istom mjestu razotkrije i kazni te samo nastave sa zlouporabama. U takvim je slučajevima ugrožen učinak poreznih kazni te je nužno ponoviti postupak razotkrivanja i kažnjavanja, i to sve do zabrane poslovanja takvim obveznicima. Kao što je već istaknuto, dosljednost i djelotvornost porezne administracije od presudne su važnosti za opću percepciju pravednosti i stvaranje društvenih pravila i normi.

\subsection{POREZNE SANKCIJE I FORMALIZACIJA PODUZEĆA}

Porezne kazne mogu dovesti do ispunjavanja poreznih obveza registriranih poduzeća, ali mogu također biti i prepreka formalizaciji poduzeća. Naravno, postoje i drugi razlozi zbog kojih poduzeća djeluju u neslužbenom sektoru. Kao osnovne prepreke formalizaciji uobičajeno se ističu složeni i teško razumljivi propisi, brojni i visoki porezi, propisi iz zakona o radu, birokracija, korupcija, itd., a ovome se popisu mogu dodati i porezne kazne.

Utjecaj poreznih kazni na formalizaciju poduzeća nije jednoznačan. Kazne se mogu promatrati iz dvije krajnosti, i to kao prepreka formalizaciji poduzeća, ili, pak, kao poziv na poslovanje u neslužbenom sektoru (tj. na neformalizaciju poduzeća). Porezne kazne prepreka su formalizaciji ako su stroge i široko rasprostranjene ili ih porezna administracija zlorabi. Broj poreznih obveza sam po sebi povećava rizik od neispunjavanja istih i s time povezanih sankcija. Ako se povrh toga u provođenju poreznih zakona previše oslanja na kazne, stvara se velika destimulacija formalizaciji poslovanja poduzeća. To je još izraženije ako sankcije nemaju nikakve veze sa stvarnim prekršajem ili su rabljene u koruptivne svrhe. Mala poduzeća, kako bi izbjegle bilo kakve obveze i mogući kontakt s vlastima, mogu izabrati da nastave poslovati u sjeni (tj. u neslužbenom gospodarstvu). U tom slučaju riskiraju da ih se otkrije i kazni, ali samo jedanput.

Porezne sankcije mogu se promatrati i kao poticaj za prelazak iz službenog u neslužbeni sektor. To se događa zbog nekvalitetno osmišljenih poreznih kazni ili manjkavosti u radu porezne administracije. Ako učinak odvraćanja i zastrašivanja nije dovoljno izražen ili je porezna administracija preslaba $u$ izvršavanju sankcija, poduzeća mogu biti sklonija poslovanju u neslužbenom gospodarstvu, ne vjerujući da su u bilo kakvoj opasnosti.

Stoga, ispravan sustav poreznih sankcija treba promatrati kao jedan od instrumenata poticanja formalizacije poslovanja poduzeća. Takav sustav ima znatan potencijal utjecaja na odluke i izbore poreznih obveznika, pogotovo ako se odvija paralelno s uklanjanjem drugih prepreka i negativnih poticaja (npr. visoke porezne obveze). U provođenju poreznih sankcija presudni su visoka učinkovitost porezne administracije te podrška obveznicima u njihovom nastojanju da se registriraju u porezne svrhe i ispune svoje porezne obveze. Bez snažnog povjerenja u poreznu administraciju i njeno ponašanje, uključujući i povjerenje u pravednost korištenih sankcija, po svoj prilici ne postoji nikakav učinkovit poticaj malim poduzetnicima da izađu iz neslužbenog gospodarstva. Međusobno povjerenje pomaže u izgradnji jakih društvenih pravila i normi. Bez tih normi, nikakva strategija za ispunjavanje poreznih obveza, a čiji su sastavni dio i porezne sankcije, ne može dati zadovoljavajuće rezultate. 
Pri izradi strategije formalizacije poslovanja poduzeća, zakonodavci i porezna administracija trebali bi se usredotočiti na nekoliko ključnih elemenata. Kada se formaliziraju, poduzeća ne bi trebala biti u lošijem položaju, rizik plaćanja većih kazni nego da su nastavili poslovati u neslužbenom sektoru trebao bi biti manji ili uopće ne bi trebao postojati, mogućnost otkrivanja i sankcioniranja eventualne utaje poreza mora biti vrlo velika, a kazne visoke u usporedbi s onima koje se primjenjuju na poduzeća koja posluju u službenom sektoru, ali su skloni pogreškama. Za povećanje učinka odvraćanja i zastrašivanja te društvene prihvatljivosti također je nužno brzo i odlučno provođenje poreznih kazni. Sve u svemu potrebno je omogućiti snažnu podršku procesu formalizacije poduzeća, a pri tome od koristi mogu biti i neke nagrade (npr. razne radionice i tečajevi, privremeni oprost ili dobro ciljani ustupci).

Nisu sve porezne administracije još uvijek dovoljno fokusirane na neslužbeni sektor. Čimbenici koji utječu na velike razlike u razmjerima neslužbenog gospodarstva među zemljama nedovoljno su istraženi, a ne zna se mnogo niti o segmentaciji stvarnih poreznih obveznika, kao ni o postojanju i potencijalnim učincima društvenih pravila i normi. Mnogim zemljama nedostaju sveobuhvatne strategije, uključujući i istraživanja najboljh mogućnosti korištenja poreznih kazni u pogledu formalizacije poduzeća i snažnijeg ispunjavanja poreznih obveza. Porezne administracije, posebno u tržištima u nastajanju, lakše se fokusiraju na poslovanje poznatih poduzeća, ignorirajući poduzeća koja su im nevidljiva. Osim fiskalnih troškova s takvim postupanjem povezan je i ogroman društveni trošak - kultura neplaćanja poreza postaje široko raširena i obuhvaća sve veći i veći broj poduzeća, pa čak i ona koja su potencijalno spremna ispuniti svoju poreznu obvezu.

Iako ne predstavljaju iznimku, iskustva iz Poljske mogu biti poučna u prikazivanju nedostataka koji se pojavljuju prilikom izrade jasne strategije za ispunjavanje poreznih obveza za mala poduzeća. Okvir I. detaljno prikazuje koliko se toga treba napraviti da bi se učinkovito riješili postojeći izazovi, od kojih mnogi od njih imaju povijesnu i kulturnu pozadinu. Poljska je zemlja visokog dohotka koja nakon raspada Istočnog bloka još uvijek ojačava demokratsku tradiciju i vladavinu prava. Problematična povijest i dugogodišnji nedemokratski režim, u kojemu je pojedinac morao varati, vješto manevrirati i izbjegavati doticaj s vlastima, uvelike su olabavili nekad snažne društvene norme i pravila te stavili stigmu na kulturu plaćanja poreza (Majka, 20Io.). Čak i danas društvo ne osuđuje porezne obveznike koji ne ispunjavaju porezne obveze. U mnogim se slučajevima oni smatraju mudracima koji znaju izigrati sustav, dok je porezna administracija okrivljena da je tiranin, čak i ako su njene aktivnosti nužne i opravdane (Debowska-Romanowska, 2008.).

OKVIR I.: POLJSKA - NEDOSTACI STRATEGIJE ZA ISPUNJAVANJE POREZNIH OBVEZA I UPORABA POREZNIH KAZNI

- Ne postoji sveobuhvatno istraživanje segmentacije i ponašanja poreznih obveznika te utjecaja osobnih i društvenih normi i pravila.

- Porezni se jaz ne računa, analize podataka o ispunjavanju poreznih obveza su ograničene, a broj podataka o veličini i strukturi neslužbenog gospodarstva je mali.

- Ne postoji sveobuhvatna strategija o poreznom administriranju MSP-a (iako postoje neke raspršene mjere, npr. ograničenja o dužini i broju revizija).

- Slaba komunikacija i svega nekoliko kampanja (no, nedavno su poduzete određene mjere, npr. medijska kampanja “Uzmi račun”, kojom se promiče ispunjavanje obveze plaćanja PDV-a).

- Ne postoji zasebna strategija odvraćanja i zastrašivanja.

- Znatno oslanjanje na porezne kazne i rijetko korištenje alternativnih instrumenata.

- Porast novčanih kazni, trenutno do I.ooo USD-a (iako se obično koriste niže kazne).

Izvor: dokumenti Ministarstva financija (www.mf.gov.pl); Akcijski plan za poboljšanje ispunjavanja poreznih obveza i veću učinkovitost porezne administracije: 20I4.-20I7. (http://www.mf.gov.pl/documents/764034/II6I625/pakiet_dzialan_podatkowych.doc); analiza autora. 
Takvo naslijeđe, koje je vjerojatno prisutno i u ostalim zemljama bivšeg Istočnog bloka, veliki je izazov za poreznu administraciju i zahtijeva ogroman trud kako bi se ispunjavanje poreznih obveza vratilo na pravi put i dosegnulo razine prisutne $u$ razvijenom svijetu. Za tako je nešto nužna i predanost istraživanju i detaljnim analizama strukture postojećih strategija za ispunjavanje poreznih obveza, uključujući i strukturu te korištenje poreznih sankcija. Do sada je u Poljskoj malo što od toga postojalo.

Takvo se stanje samo djelomično može objasniti ograničenjima kapaciteta i sposobnosti poreznih administracija. Drugi čimbenici odnose se na nedovoljno razvijenu svijest o postojećim izazovima, ograničeno iskustvo u primjeni bihevioralne ekonomije, i još važnije - nedostatak političke volje.

\section{CILJEVI I OBLIGI POREZNIH SANKCIJA}

Porez je obvezno plaćanje državi, bez protučinidbe3. Nepovratna je činidba u smislu da usluge koje izvršne vlasti daju nisu razmjerne plaćanjima poreznih obveznika. Budući da ne postoji izravna korist, obveznici se po prirodi stvari opiru plaćanju poreza. Otpor plaćanju poreza razlikuje se među poreznim obveznicima, ali je u velikoj mjeri razmjeran ukupnom poreznom opterećenju, kvaliteti oporezivanja te percepciji učinkovitosti državne potrošnje.

Neupitno je da što je veća prihvaćenost poreza, poreznoj je administraciji prikupljanje poreza lakše. No, previše bi optimistično bilo oslanjati se samo na unutarnje uvjerenje poreznih obveznika kako je plaćanje poreza ispravna stvar koju treba napraviti. Zakonska prisila i sankcije još uvijek su nužni kako bi se naplatili porezi. Obveze moraju ići ruku pod ruku sa sankcijama (Ripstein, 2004.). U suprotnome će postati klasični lege imperfecta (manjkavi zakon), što je nezamislivo u domeni javnih financija (Dębowska-Romanowska, 2008.).

Stoga, ključno pitanje nije treba li sankcije koristiti, nego kako bi trebale izgledati. Iako univerzalan odgovor na ovo pitanje ne postoji, pojavljuju se dva osnovna elementa. Prvi, porezne bi sankcije trebale utjecati na ponašanje poreznih obveznika - spriječiti nepoštivanje tj. neispunjavanje obveza i poticati ponašanje koje bi u budućnosti vodilo ka njihovu ispunjavanju. Drugi, sankcije bi trebale biti veće i bolnije nego je to samo ispunjavanje porezne obveze, ali još uvijek ne smiju biti represivne.

Preventivni aspekt porezne sankcije uglavnom leži u odvraćanju i zastrašivanju (Wenzel, 2004.; OECD, 20Io.; Majka, 20Io.). Porezni se obveznici radije odlučuju pridržavati svojih poreznih obveza, nego da plate veći iznos od troška ispunjavanja obveze ili izgube potencijalne porezne koristi (npr. porezne ustupke). Međutim, to je točno samo ako obveznici znaju posljedice nepoštivanja i neispunjavanja poreznih obveza, smatraju da nije isplativo varati i vjeruju da bi mogli biti otkriveni.

Osim toga, porezne sankcije i motiviraju obveznike. Kao prvo, mogu ih educirati, ali samo ako su pravedne i neminovne. Izvjesnost da će biti otkriveni i kažnjeni preduvjet je edukacije obveznika (Frey i Feld, 2002.; Torgler, 2007.). Drugo je pitanje pravičnost primijenjene sankcija. Ako su preblage, porezni obveznici mogu smatrati da im je opet korisnije ne ispunjavati porezne obveze. Ako su pak prestroge, obveznici ih mogu smatrati previše represivnim i neprihvatljivim te će vjerojatno odabrati izigravanje poreznog sustava, čak i ako to ranije nisu činili. Kao drugo, porezne sankcije mogu doprinijeti stvaranju ili promicanju društvenih normi i pravila. Ako drugi obveznici porezne sankcije smatraju pravednima, tada one izgrađuju osjećaj pravde i nagrađuju one koji redovito ispunjavaju svoje obveze. Istovremeno se šalje i jasna poruka kako je plaćanje poreza ispravna stvar koju treba napraviti, obveznici su iskreni i

3 Iako ne postoji jedinstveni stav i konsenzus o tretmanu drugih naknada, pristojbi i doprinosa za socijalno osiguranje obveznici ih doživljavaju kao poreze, čak i ako postoji izravna korist od takvih plaćanja (npr. pružene usluge, izdane dozvole). 
pošteni - a kažnjena je samo nekolicina obveznika koja ne ispunjava svoje porezne obveze. U ispunjavanju poreznih obveza takva pravila i norme obveznike, pogotovo individualna mala poduzeća, jako motiviraju (Torgler, 2007.; Popplewell i sur., 2012.).

Kao što je ranije istaknuto, ako su preblage porezne sankcije nisu pravedne. Kažnjavajuće su samo ako ih porezni obveznici smatraju težima i bolnijima od ispunjenja porezne obveze. Zbog toga, svaka porezna sankcija mora imati i razumno financijsko značenje, i to opet uglavnom kako bi se obveznike zastrašilo i ograničilo u neispunjavanju poreznih obveza te ih motiviralo ka njihovu ispunjavanju. Za razliku od kaznenih, porezne sankcije ne bi trebale imati za svrhu represiju (Majka, 20Io.). Društvo i dalje treba poduzetnike koji će i u budućnosti plaćati poreze, a ne bi trebalo biti zainteresirano za teške kazne koje dovode do zatvaranja poduzeća. Naravno, to ne bi trebao biti slučaj s poduzećima osnovanima isključivo u svrhu poreznih prevara. Ako je riječ o ozbiljnim kaznenim djelima porezne bi kazne trebale dovesti do prestanka takvih aktivnosti. Na primjer, ako su mala poduzeća registrirana za potrebe PDV-a samo kako bi iskoristila lažne povrate PDV-a, porezna uprava ima interes $\mathrm{u}$ ultimativnom zatvaranju takvih poduzeća. Ne postoje nikakve fiskalne ili društvene koristi od omogućavanja nastavka poslovanja takvim poduzećima. Kako bi se postigao taj cilj, moguće je rabiti jako ozbiljne i stroge kazne.

Porezne sankcije ne bi smjele biti uvedene s isključivom svrhom prikupljanja prihoda (DebowskaRomanowska, 2008.). Sveobuhvatni je cilj dobro osmišljenog i upravljanog poreznog sustava stvaranje situacije u kojoj svi porezni obveznici poštuju i ispunjavaju svoje porezne obveze, a kazne se niti ne rabe. U tome smislu nijedna vlada ne bi trebala računati na prihode od poreznih kazni. Bilo koji primici po toj osnovi samo su posljedica nesavršenosti kako poreznih obveznika tako i porezne administracije. Porezne bi kazne trebalo smatrati posljednjim izborom mjera za ispravljanje takvih nedostataka, a nipošto učinkovitim izvorom prihoda. Povećanje prihoda od poreza na kazne ponajprije bi trebalo protumačiti kao pokazatelj pada kvalitete oporezivanja, a ne kao pokazatelj veće učinkovitosti porezne administracije. Izvršnu bi vlast trebalo ohrabriti u poduzimanju potrebnih radnji u cilju poticanja dobrovoljnog ispunjavanja poreznih obveza i vraćanja postupanja i prakse porezne administracije na ispravan put.

Obeštećenje (kompenzacija) također nije cilj poreznih sankcija (Majka, 20IO.). Svaka uplata poreznih obveznika kojom se nadoknađuje gubitak prihoda proračuna (npr. kamate na dospjele neplaćene porezne obveze tj. porezni dug, eng. interest paid on tax arrears) ne predstavlja poreznu sankciju. Ako kompenzacija nije veća od učinjene štete (gubitka prihoda) ne trpi nitko ("nema elementa boli") i to treba shvatiti samo kao puki čin naknade (restitucije), a ne kao poreznu kaznu. Brojni primjeri upućuju da ju takvom percipiraju i sami porezni obveznici.

Postoji cijeli niz različitih poreznih sankcija - od standardnih novčanih kazni koje administriraju porezne vlasti do sofisticiranijih mjera kao što su povećane porezne stope, dodatna plaćanja poreza i sl. I neki drugi postupci i rješenja, čak i ako nenamjerna, za porezne obveznike mogu predstavljati kaznu.

Najčešće korišten oblik poreznih sankcija su novčane kazne. Administriraju ih porezne uprave, bez posredovanja sudova, i to kad god se otkrije nepoštivanje i neispunjavanje porezne obveze. U zakonima mogu biti navedene $\mathrm{u}$ fiksnim iznosima ili, rjeđe, nametnute $\mathrm{u}$ odnosu na prihode obveznika, dobit, promet, vrijednost imovine poduzeća, ili bilo koji drugi lako uočljiv element. Rijetko su u svezi sa stvarnim poreznim umanjenjem. Kao prvo, ne dovodi baš svako neispunjavanje porezne obveze do manjih uplata poreza, npr. nedostatak ili naknadne prijave, nedostaci u poreznim knjigama i 
izračunima. Kao drugo, novčane se kazne obično izriču odmah nakon što se otkrije slučaj neispunjavanja porezne obveze, bez ikakvog nepotrebnog odgađanja. Tako bi nešto od porezne uprave zahtijevalo temeljitu analizu svakog pojedinog slučaja kako bi utvrdila iznos neplaćenog poreza kao posljedicu neispunjavanja porezne obveze.

Drugi oblici poreznih sankcija mogu uključivati povećane porezne stope i dodatne porezne obveze(npr. dodatna plaćanja PDV-a izračunata u postotku od umanjene prijave poreza, eng. under-declared). Postupni porast kamata na porezni dug, ovisno o starosti nepodmirenih dugovanja, također po svojoj prirodi predstavlja kaznu u budućnosti - ako prelaze iznos redovnih kamata na porezni dug.

Zakonska podloga poreznih sankcija za porezne je obveznike nevažna. Obveznici poreznom kaznom mogu smatrati bilo koju mjeru koja je posljedica kršenja poreznih obveza i dovodi do neravnopravnog gospodarskog položaja u usporedbi sa situacijom kada se porezne obveze poštuju. Zakonska prisila obično je povezana sa sankcijama. Međutim, mogu postojati i sankcije bez ikakve prisile, npr. opoziv poreznih ustupaka i uskraćivanje određenih prava. Ako je obveznik koristio pojednostavljeni oblik oporezivanja ili ubrzanu amortizaciju pa mu se to pravo oduzme, zasigurno za obveznika postoji "element boli", u usporedbi sa situacijom koja proizlazi iz tradicionalnih poreznih sankcija.

Tradicionalno, za obveznike koji ne ispunjavaju svoje porezne obveze porezne sankcije predstavljaju samo mjere donesene s jasnim ciljem osiguranja prihvatljive "razine boli". Neke, pak, mjere čak i ako nemaju za cilj kažnjavanje, po svome su učinku sankcije. Brojni su primjeri poreza koji izravno kažnjavaju obveznike ili uzrokuju neispunjavanje poreznih obveza, a obveznike čine osjetljivima na tradicionalne sankcije. U prvu skupinu mjera mogu spadati npr. nepostojanje alternativnih mogućnosti odabira oporezivanja pretpostavljenim porezom za mala poduzeća ili nepostojanje mogućnosti dobrovoljne registracije za potrebe PDV-a. Mali obveznici mogu izabrati da se oporezuju pretpostavljenim porezom, no nakon nekog vremena mogu uvidjeti kako im nastavak takvog oporezivanja ne donosi nikakve koristi (npr. ako njihove marže drastično padnu, a oporezivanje njihovog prometa postane preveliko u usporedbi s oporezivanjem stvarnih prihoda prema općem poreznom režimu). Ako je izbor pretpostavljenog oporezivanja vremenski određen i fiksan, a prebacivanje na opći porezni režim nije moguć, mala su poduzeća prisiljena plaćati veće poreze. U tom slučaju to za njih predstavlja kaznu. Isto tako, iako velika većina malih poduzeća korisnim smatra mogućnost izuzeća od PDV-a, neka od njih (npr. izvoznici ili oni koji usluge isporučuju uglavnom obveznicima PDV-a) mogu biti životno zainteresirana za registraciju za potrebe PDV-a. Ako im to nije dopušteno, kažnjeni su te moraju prihvatiti niže marže kako bi ostali konkurentni.

Druga skupina poreznih rješenja koja na porezne obveznike može imati učinak kazne odnosi se na prevelike porezne obveze i kvalitetu poreznih zakona. Pretjerani zahtjevi za izvješćivanjem, kratki rokovi za ispunjavanje porezne obveze, kao i nesrazmjerna uvjetovanost poreznih ustupaka često nisu opravdani, ali se pridodaju troškovima ispunjavanja porezne obveze. U tome se smislu mogu smatrati sankcijama, čak i više ako se usporede s mogućnosti ostanka u neslužbenom sektoru. Nedostatak jasnih poreznih propisa i česte promjene poreznih zakona dodatno kompliciraju ispunjavanje poreznih obveza. Takva obilježja poreza i poreznih propisa mogu potaknuti neispunjavanje poreznih obveza -

\footnotetext{
4 Svrha ovog članka nije razmatranje različitih mjera porezne politike koje mogu predstavljati kazne, bilo namjerne, npr. obeshrabrivanje potrošnje određene robe (trošarinama na duhan i alkoholna pića), bilo nenamjerne, npr. davanjem odbitaka od porezne obveze za bračne parove s djecom kažnjeni su obveznici samci ili bez djece ili penaliziranje dugoročne štednje složenim ukamaćivanjem, itd.
} 
ako obveznici nisu svjesni svojih obveza ili imaju malo vremena za djelovanje - vjerojatnije je da će napraviti pogrešku i kasniti, izlažući se tradicionalnim poreznim kaznama.

Porezne sankcije i veliku zapreku poslovanju također može predstavljati i nepravilno postupanje poreznih administracija (Silvagni i Baera, I997.; IFC, 2007.; McClellan, 2013.). Nepravilne i manjkave porezne odluke, duže trajanje poreznih žalbi, česte revizije, naknadne isplate povrata PDV-a, itd., stvaraju neizvjesnost i povećavaju troškove poslovanja. Kao takve, one predstavljaju neizravne sankcije. Ako kao posljedica neispravnih odluka porezne uprave (npr. kamate na zakašnjele povrate PDV-a, naknada za pogrešne porezne odluke, itd.) ne bude plaćena niti jedna odšteta, tada ovakvi postupci postaju prava porezna kazna koja je bolnija čak i od tradicionalnih kazni.

Porezne sankcije mogu značajno utjecati na ekonomsko poslovanje. One povećavaju tekuće (operativne) troškove poslovanja, i to ne samo za iznos plaćene kazne nego i za iznos s time povezanih troškova postupka i žalbi, ako se dogode. Kako porezne kazne, s pravom, nije moguće odbiti za potrebe izračuna porezne obveze, one utječu i na stopu povrata nakon oporezivanja. Fiksni paušalni izdaci ili kazne izražene $u$ postotku prometa ili vrijednosti imovine imaju različito značenje za tvrtke $s$ izraženom profitabilnošću. No, ako nisu adekvatno postavljene, tada su regresivne.

\section{TEŽINA POREZNIH SANKCIJA}

Čini se kako veći učinak zastrašivanja i odvraćanja ima vjerojatnost da obveznik bude otkriven nego sama težina kazne (Tullock, 1974.; Majka, 2OIO.; OECD, 2010.; Popplewell, 2012.). Ako porezni obveznici vide kako je sve teže ostati neuhvaćen (npr. uslijed rizika i kvalitetnije ciljanih revizija ili sofisticiranijih informatičkih rješenja), nastavak s praksom utaje poreza mogu smatrati prerizičnom. Ako, pak, vide kako su se samo povećale potencijalne porezne kazne, neće se bojati ništa više nego ranije. Doista, za malog poduzetnika nema velike razlike između 50, 70 ili 90 postotne porezne stope za kaznu; ili između 5.000 i 6.000 USD-a novčane kazne. Sve se te kazne čine podjednakima u smislu učinka odvraćanja i zastrašivanja od takvog postupanja ili su, pak, poreznim obveznicima nevažne. Naime, odaziv obveznika na potencijalno strože i veće porezne kazne nije proporcionalan.

Stoga sve strože i strože porezne sankcije nemaju stvarnog utjecaja na ponašanje poreznih obveznika. No, to opet ne znači i da porezne sankcije ne bi trebalo revidirati i preispitati, nego upravo suprotno. Kreatori politika i porezni službenici trebali bi ih imati na svome dnevnom redu, prvo u obliku sveobuhvatnog pregleda sustava kazni, a onda i u vidu njihova povremenog ocjenjivanja kako bi bili sigurni da su popis i razina samih kazni odgovarajući s obzirom na promjene poslovnog okruženja kao i gospodarske, društvene i kulturne promjene. Iskustvo bi Ujedinjenog Kraljevstva pri tome moglo biti poučno. HMRC 5 je 2008. u okviru strategije poboljšanja ispunjavanja poreznih obveza pokrenuo analizu i pregled svog sustava kazni za kašnjenje ili nepodnošenje poreznih prijava i plaćanje obveza (HMRC, 2008.).

Nametnute porezne sankcije svakako su važne za porezne obveznike i društvo. S jedne strane moraju biti dovoljno bolne kako bi obeshrabrile obveznike u neispunjavanju poreznih obveza. S druge strane moraju biti i prihvatljive i pravedne, a nikako represivne. Teško je za porezne sankcije postaviti nekakve limite (Debowska-Romanowska, 2008.; Majka, 2010.). U tome je opet ključna uloga nositelja političkih odluka i poreznih administracija. Oni za porezne sankcije prvenstveno moraju osmisliti odgovarajući

${ }^{5}$ Her Majesty's Revenue and Customs - naziv porezne uprave u Ujedinjenom Kraljevstvu (op. prev.). 
popis, oblike te ograničenja i rokove, a nakon toga, ako postoji prostor za donošenje diskrecijskih odluka porezne administracije, moraju odabrati i prikladnu kaznu.

Nemoguće je dati konačan odgovor na pitanje kako bi trebala izgledati savršena porezna kazna. No, bez obzira na to, trebalo bi definirati neke temeljne smjernice za postojanje učinkovitih sankcija.

Prvo, moraju biti dovoljno bolne, odnosno bilo kakav izračun analize troškova i koristi za obveznika učiniti besmislenim i uzaludnim. Poreznim obveznicima ispunjavanje poreznih obveza mora biti povoljnije i korisnije od mogućnosti neispunjavanja poreznih obveza. Obveznici moraju voditi računa o financijskim potrebama države, ali i o predvidivosti kretanja svojih prihoda. Široko je prihvaćeno mišljenje kako porezni obveznici ne bi smjeli neplaćene poreze iskoristiti kao izvor prihoda za financiranje svojih poslovnih aktivnosti. Kamate na porezne dugove (dospjele, a neplaćene obveze) osnovni su instrument sprječavanja takvih situacija i određena odšteta državi zbog kašnjenja u plaćanjima. Porezne sankcije, npr. novčane kazne i dodatno povećanje kamata na porezne dugove iznad uobičajene standardne stope, samo su još jedan od dodatnih načina osiguranja pravovremenih plaćanja. Uloga je poreznih sankcija da neispunjavanje poreznih obveza učini beskorisnim i bolnim. Procjena podcijenjenih poreza i plaćanje kamata nije nepovoljan čimbenik jer predstavlja samo povrat onoga što treba biti plaćeno i odštetu za gubitak vrijednosti novca tijekom vremena.

Drugo, porezne sankcije ne smiju biti preoštre ili pogubne. Pretjerana represija nikad nije uspijevala, i to ne samo na području oporezivanja. Poučno je iskustvo zemalja Istočnog bloka u kojima su komunistički režimi za bilo koji oblik neispunjavanja poreznih obveza nametali drakonske kazne, ali je unatoč tomu evazija bila raširena (Majka, 2010.).

Prilikom osmišljavanja pravednih sankcija potrebno je uravnotežiti željenu težinu kazne i njenu nerepresivnost. To znači kako pravedna sankcija treba u obzir uzeti i druge čimbenike. Ona mora prepoznati vrstu neispunjavanja poreznih obveza. Bilo bi nekorektno na isti način kažnjavati povremene pogreške i namjerne prevare. Također je važna i vrsta prekršaja prilikom ispunjavanja porezne obveze - zakašnjelo ispunjavanje porezne obveze razlikuje se od namjernog manje prijavljenog (podcijenjenog) poreza. No, najvažnije je pravedne sankcije prilagoditi platežnoj sposobnosti obveznika. Novčana kazna od Ioo USD-a različito znači kovaču i odvjetniku, jer vjerojatno rade na različitim tržištima i s drugačijim maržama. Isto tako, Io postotna kazna od prometa obveznika ima različit udio u profitabilnosti trenutnog poslovanja poduzeća koja se, pak, znatno razlikuje među sektorima.

U zakonu bi trebalo predvidjeti i razumnu listu mogućih prekršaja i ukazati na raspon potencijalne kazne ili kazni. Ne mora to biti pretjerano kazuistički, tj. da predvidi sve moguće vrste neispunjavanja poreznih obveza i okolnosti prekršaja. Propisivanje fiksnog iznosa novčane kazne također nije kvalitetno rješenje. Dobrim pristupom čini se definiranje raspona ili barem gornje granice (visine) sankcije, osobito u slučaju kazni izraženih u iznosima, a ne u postocima. Takvo postupanje poreznim administracijama daje određenu razinu diskrecije, kako s obzirom na kvalifikaciju određenog prekršaja tako i na stvarno izrečenu kaznu, čime joj se u danim okolnostima omogućuje i odabir ispravne i pravedne kazne. U zemljama sa slabom poreznom administracijom, jasno upozorenje za porezne prekršaje uz postavljanje granica primjene poreznih sankcija omogućuje, barem u nekoj mjeri, ograničavanje mogućnosti pretjeranog tlačenja i zlostavljanja poreznih obveznika.

Drugi je izazov uporaba informatičkog sustava u administriranju poreznih kazni. IT sustavi sastavni su dio svake moderne porezne administracije i nužni su za učinkovit nadzor poreznih obveznika u pogledu 
poštivanja i ispunjavanja njihovih obveza. Ako se koriste za provjeru i kontrolu ispunjavanja poreznih obveza (npr. zakašnjela prijava ili neispunjavanje obveze, potrebna izvješća, plaćanja poreza, itd.), tada IT sustavi lako mogu otkriti obveznike koji ne ispunjavaju svoje porezne obveze. Sustavi se mogu programirati na način da automatski izriču novčane kazne (ili neke druge sankcije) u svakom pojedinom razotkrivenom slučaju neispunjavanja poreznih obveza te obavijeste obveznike bez posredovanja službenih poreznih tijela. To znatno ubrzava administrativne procese i smanjuje ne samo količinu posla kojega bi inače morali odraditi porezni službenici, nego i rizik zlouporabe s njihove strane. No, može se činiti i kako je ovakav pristup "bezdušan" i suprotan ideji postojanja pravedne porezne sankcije. Osim ako se ne rabi tzv. "mudri" algoritam koji u obzir može uzeti većinu relevantnih okolnosti (npr. nedavno pokretanje posla, prvo kašnjenje u ispunjavanju ili plaćanju obveze), nužno je provjeriti izrečene kazne, i to, ako ne ranije, onda putem pojednostavljene žalbe.

Pooštravanje poreznih sankcija za zakašnjelo ispunjavanje poreznih obveza (npr. za podnošenje prijave) djelomično može uvesti pravičnost u sustav poreznih sankcija. Ako je svrha sankcioniranja zakašnjelog ispunjavanja obveze potaknuti pravovremeno podnošenje porezne prijave, ili barem potaknuti njezino podnošenje što prije nakon isteka roka, pravednim se čini postupno povećati iznos kazne - što kasnije obveznik ispuni svoju obvezu, veću neugodnost doživljava (tj. plaća veću kaznu). Stvarni izgled takvo osmišljenih rastućih sankcija - bilo u obliku dopunskog poreza (prireza) ili u proporcionalnom iznosu - u velikoj mjeri ovisi o kapacitetu porezne administracije te odgovoru i reakciji obveznika na porezne kazne (MMF, 2004.).

\section{ALTERNATIVE POREZNIM KAZNAMA}

Bez povezivanja s drugim mjerama i postupcima, samo oslanjanje na porezne sankcije u poštivanju i izvršenju poreznih obveza, nije se pokazalo učinkovitim. Povećanje visine (težine) kazni također nije od koristi. Sukladno tome, potrebno je razviti sveobuhvatnu strategiju postupanja prema poreznim obveznicima, temeljenu na ravnoteži između poreznih kazni i onih mjera koje ispunjavanje poreznih obveza u prvom redu nastoje potaknuti kroz veću podršku i suradnju s obveznicima. To je stara dilema "štapa i mrkve" - u kojoj mjeri koristiti svaku od navedenih dviju skupina mjera kako bi se postigli najbolji mogući rezultati. Jednostavnih odgovora nema; no postoje razlozi vjerovati da veći naglasak treba staviti na drugu grupu. Iako je to svojevrstan izazov, neka rješenja postoje.

Porezne administracije korisnim mogu smatrati uporabu neizravnih i izravnih alternativa poreznim sankcijama. Porezna uprava ispunjavanje poreznih obveza neizravno može potaknuti davanjem veće podrške malim poduzećima, posebice start-up-ovima (malim poduzećima koja tek pokreću poslovanje, op. prev.), te izgradnjom međusobnog povjerenja svojom profesionalnošću, učinkovitom komunikacijom, obukom i tehničkom podrškom (Silvani i Baer, 1997; Hadler, 2000.). Na ovaj se način smanjuje potreba nametanja kazni koje se mogu koristiti tek kao zadnja mogućnost, tj. u slučaju kada druge mjere ne daju željene rezultate.

U slučaju otkrivanja neispunjavanja porezne obveze, tamo gdje je moguće, potrebno je razmisliti o davanju upozorenja, kao izravnoj alternativi poreznoj sankciji. Osim što odvraćaju od neispunjavanja obveza, upozorenja mogu predstavljati i određenu podršku. S jedne su strane takva upozorenja znak poreznom obvezniku da ga porezne vlasti promatraju i da u slučaju neispravljanja pogreški u smislu neispunjavanja poreznih obveza mogu poduzeti i daljnje mjere (učinak odvraćanja). S druge strane, ona upozoravaju obveznika na počinjenu pogrešku te da njeno ispravljanje zahtijeva njegovo djelovanje 
(učinak podrške). Ako porezni obveznik ne ispravi svoje pogreške niti zatraži pomoć porezne administracije u rješavanju problema, porezna administracija mora biti odlučna u uporabi i nametanju pravednih poreznih sankcija.

Korištenje komunikacijskih sredstava i provjera na licu mjesta također po svojoj prirodi imaju učinak odvraćanja (OECD, 20Io.). Povremena komunikacija putem internetske stranice, elektronske pošte i drugih medija o planiranim kampanjama (npr. provjera sezonskog poslovanja u ljetnim ili zimskim odmaralištima) prilično mogu obeshrabriti obveznika od iskorištavanja postojećih mogućnosti. Povremene kontrole općenito, ako se odgovorno koriste, mogu imati slične učinke kao i porezne sankcije. No, prečeste kontrole poreznog obveznika koji redovito ispunjava svoje porezne obveze mogu se smatrati tlačenjem koje na koncu daje upravo suprotne rezultate, tj. niže razine ispunjavanja poreznih obveza. Ako je sankcija opravdana, trebalo bi razmisliti o korištenju nenovčanih kazni. Takve nenovčane kazne uključuju određeni stupanj neugodnosti, ali ne utječu izravno na poslovanje poduzeća jer nema nikakvog plaćanja kazne. Objava imena obveznika koji ne ispunjavaju svoje porezne obveze, provođenje obveznih tečaja o ispunjavanju poreznih obveza ili više razine nadzora i provjera za obveznika mogu imati jednako bolan učinak kao i tradicionalne porezne kazne te ga odvraćati od neispunjavanja porezne obveze.

Zakonodavci također mogu dati svoj doprinos manjoj uporabi poreznih sankcija. Osim osiguravanja transparentnosti i jednostavnosti poreznog zakona, uravnoteženosti poreznih obveza i dobre ciljanosti ustupaka za mala poduzeća, oni bi trebali razmotriti i usvajanje brojnih, tzv. "nagrada za poštivanje zakona". Takva specifična rješenja motiviraju porezne obveznike da ispunjavaju porezne obveze kako bi ostvarili i druge pogodnosti, kao što su npr. odbitak fakturiranih troškova, jasni porezni registri za sudjelovanje u javnoj nabavi, obnova poslovnih licenci ili čak registracija automobila, ubrzana isplata povrata PDV-a, itd. Sve u svemu vjerojatno je kako će porezni obveznici vrijednost takvih nagrada cijeniti više od potencijalnih dobitaka koje bi ostvarili od neispunjavanja poreznih obveza.

\section{ZAKLJUČAK}

Problematika ispunjavanja poreznih obveza malih poduzeća zahtijeva posebnu pozornost. S jedne strane mala poduzeća često nisu u stanju ispuniti sve svoje porezne obveze, osjetljivija su na vanjske rizike (npr. ekonomske šokove, nepošteno tržišno natjecanje, nedostatak transparentnosti i zlouporabu) i u iskušenju su da iskoriste različite mogućnosti neispunjavanja poreznih obveza. S druge strane, za razliku od velikih, kada je riječ o malim poduzećima obično se radi o poduzećima s jednim vlasnikom ili poduzećima kojima upravljaju sami vlasnici zbog čega su veoma osjetljiva na osobne, socijalne, kognitivne i emocionalne čimbenike. Ovakve značajke otvaraju putove boljem korištenju mjera fokusiranih na ponašanje i odluke poreznih obveznika. Porezne su sankcije jedna od bihevioralnih mjera koje se mogu učinkovito rabiti pri adresiranju izazova koje sa sobom nosi pitanje ispunjavanja porezne obveze. Odvraćanjem, motivacijom, pravednim pristupom te stvaranjem poželjnih društvenih normi porezne sankcije mogu utjecati na odluke i izbore poreznih obveznika te zbog toga imaju važnu ulogu u poticanju formalizacije poduzeća i povećanja stupnja ispunjavanja porezne obveze.

Da bi se ovaj cilj postigao, zakonodavci i porezni službenici trebali bi itekako biti svjesni postojanja nekoliko izuzetno važnih obilježja i izazova koje porezne sankcije povlače. U prvom redu treba istaknuti kako su porezne sankcije važne i još uvijek nužne. One sankcioniraju nepropisno ponašanje poreznih 
obveznika i olakšavaju izvršenje i naplatu poreza. Međutim, najbolje rezultate pokazuju ako se koriste kao dodatak drugim mjerama koje poboljšavaju stupanj ispunjavanja poreznih obveza te se porezna administracija ne bi trebala oslanjati samo na porezne sankcije. Porezni režim ili administracija čiji se rad suviše orijentira na sankcioniranje i kažnjavanje važna je prepreka formalizaciji poduzeća te destimulira ispunjavanje poreznih obveza. Prilično rasprostranjeno korištenje poreznih sankcija djeluje protivno na stvaranje pozitivnih društvenih normi i pravila te kulture plaćanja poreza.

Kao drugo, porezne bi sankcije, umjesto da služe za prikupljanje dodatnih prihoda, trebale biti osmišljene na način da obveznike odvrate od neispunjavanja i motiviraju ih u ispunjavanju poreznih obveza. Porezne sankcije, čak i ako se koriste za osiguravanje poreznih prihoda, ne bi trebalo promatrati isključivo kao izvor prihoda.

Konačno, sve strože i veće porezne kazne uopće nisu učinkovite - pravednost i brzo izvršenje obveza mnogo su važniji, baš kao i slanje poruke onim obveznicima koji redovito ispunjavaju sve svoje obveze da se porezna administracija ozbiljno bavi poreznim prekršajima u vezi neispunjavanja poreznih obveza. Ako je neophodno, porezne sankcije moraju biti visoke i bolne, ali ne i slijepe odnosno moraju uzeti u obzir i osobnu situaciju poreznog obveznika, vrstu i razloge nepoštivanja i neispunjavanja poreznih obveza kao i sposobnost obveznika da plati kaznu. Zakašnjele obavijesti o promjeni adrese obveznika ne bi trebalo kazniti istom mjerom kao namjerno iskazivanje manjih iznosa poreza. Također, paušalna kazna u fiksnom iznosu različito znači poduzećima s visokom profitabilnosti. Drugi instrumenti mogu imati bolji učinak od porezne sankcije; zakonodavci i porezna administracija, gdje god je to moguće, trebaju radije koristiti druge načine i instrumente odvraćanja i zastrašivanja (npr. provjere, upozorenja, komunikaciju), nenovčane kazne te nagrade za poštivanje zakona. Akcije podrške i stvaranje povjerenja u poreznu administraciju također mogu poticati i unaprijediti ispunjavanje porezne obveze. Uostalom, učinkovita uporaba poreznih sankcija zahtijeva poznavanje segmentacije poreznih obveznika, bihevioralnih reakcija te osobnih, društvenih i kulturnih normi i pravila. 


\section{REFERENCE}

I. Allingman, M. i Sandmo, A., 1972. Income Tax Evasion: A Theoretical Analysis. Journal of Public Economics, I, str. 323-338. doi: 10.1016/0047-2727(72)90010-2

2. Ayadi, R. i Gadi, S., 2013. Access by MSMEs to Finance in the Southern and Eastern Mediterranean: What role for credit guarantee schemes?. Technical Report, No. 35/2013. Bruxelles: European Commission.

3. Chen, D., Lee, F. i Mintz, J., 2002. Taxation, SMEs and Entrepreneurship. OECD Science, technology and Industry Working Papers, 2002/o9.

4. Coleman, C. i Freeman, L., 1997. Cultural foundations of taxpayer attitudes to voluntary compliance. Australian Tax Forum, I3(3), str. 3II-336.

5. Cowell, F., 2003. Sticks i Carrots. DARP Discussion Paper, No. 68. London: London School of Economics and Political Science.

6. Crawford, C.i Freedman, J., 2010. Small Business Taxation, in: S. Adam [et al.], eds. Dimensions of Tax Design. The Mirrlees Review. London: Institute for Fiscal Studies; Oxford: University Press.

7. Crocker, K. i Slemrod J., 2004. Corporate tax evasion with agency costs. NBER Working Paper, No. I0690.

8. Darvas, Z., 2013. Banking System Soundness is Key to SME Financing. Bruegel Policy Contribution, Issue 2013/IO.

9. Dębowska-Romanowska T., 2008. Za co karać podatnika, a za co powinno odpowiadać państwo w stosunku do działających w dobrej wierze podatników? Prawo i podatki, (I).

Io. Devos, K., 2004. Penalties and Sanctions for Taxation Offences in New Zealand: Implications for Taxpayer Compliance. New Zealand Journal of taxation Law and Policy, Io (3), str. 212-244.

II. ECB, 2013. Survey on Access to Finance of Small and Medium-sized Enterprises in the Euro Area [online]. Dostupno na: <https://www.ecb.europa.eu/pub/pdf/other/accesstofinancesmallmediumsizedenterprises201404en.pdf??da92046852830off549d8cc95522eb81>.

I2. Engelshalk, M., 2004. Creating a Favorable Tax Environment for Small Business in: J. Alm, J. Martinez-Vazquez and S. Wallace, eds. Taxing the Hard-to-Tax: Lessons from Theory and Practice. Amsterdam: Elsevier.

13. Engstom, P. i Holmlund, B., 2006. Tax-Evasion and Self-Employment in a High-Tax Country: Evidence from Sweden. Working paper Series of the Department of Economics, No.I2. Sweden: University of Uppsala.

I4. Evans, C., Carlon, S. i Massey, D., 2005. Record keeping practices and tax compliance of SMEs. eJournal of Tax Research, 3(2), str. 288-334.

15. Frey, B. i Feld, L., 2002. Deterrence and morale in taxation: An empirical analysis. Working paper, No. 760 .

16. Hadler, S., 200o. Best Practice in Tax Administration in Sub-Saharan Africa: A Handbook for Officials. Cambridge, MA: International Tax Program, Harvard Law School.

17. HMRC, 2008. Modernizing Powers, Deterrents and Safeguards. Meeting the obligations to file returns and pay tax on time. London: HMRC

18. IFC, 2007. Designing a Tax System for Micro and Small Businesses: Guide for Practitioners. Washington DC: IFC.

19. IMF, 2004. How Should the Penalty for Late Filing of a Tax Return Be Structured? Dostupno na: 〈http://www.imf.org/external/np/leg/tlaw/2004/notes/eng/late.htm〉.

20. Kirchler, E., Muehlbacher, K. i Wahl, I., 2007. Why pay taxes? A review of tax compliance decisions. Working Paper, No. 07-30. Georgia State University.

2I. Kitching J., 20II. Adapting to a Fragile Recovery: SME Responses to Recession and Post-Recession Performance. Dostupno na: 〈http://www.isbe.org.uk/content/assets/John_Kitching.pdf〉.

22. Majka, P., 20Io. Sankcje w Prawie Podatkowym. Torunski Rocznik Podatkowy - Rocznik, str. 25-88.

23. Matthews, R., 2005. The myth of punitiveness. Theoretical Criminology, 9 (2), str. I53-174. doi: 10.1177/1362480605051638 
24. McClellan, G., 2013. The Consequences of Poor Tax Administration: Collections, Growth, and Corruption. Dissertation. Georgia State University. Dostupno na: $\langle$ http://scholarworks.gsu.edu/econ_diss/90〉.

25. McKerchar, M., 1995. Understanding small business taxpayers: Their sources of information and level of knowledge of taxation. Australian Tax Forum, I2, str. 25-4I.

26. OECD, 2009. Taxation of SMEs. Key Issues and Policy Considerations. OECD Tax Policy Studies, No. I8. Paris: OECD.

27. OECD, 2010. Understanding and Influencing Taxpayers' Compliance Behaviour Information Note. Forum on Tax Administration: SME Compliance Subgroup. Paris: OECD.

28. OECD, 2012. Right from the Start: Influencing the Compliance Environment for Small and Medium Enterprises Information Note. Forum on Tax Administration: SME Compliance Subgroup. Paris: OECD.

29. OECD, 20I4. Tax Compliance by Design. Achieving Improved SME Tax Compliance by Adopting a System Perspective. Paris: OECD.

30. Ogawa, K. i Tanaka, T., 2012. The Global Financial Crisis and Small- and Medium-sized Enterprises in Japan: How did they cope with the crisis? Discussion Paper Series, I2-E-o12. Tokyo: Research Institute of Economy, Trade and Industry.

3I. Ozturk, B. i Mrkaic, M., 20I4. SMEs' Access to Finance in the Euro Area: What Helps or Hampers? IMF Working Paper, WP/14/78.

32. Poppelwell, E., Kelly, G. i Wang, X., 2012. Intervening to reduce risk: identifying sanction thresholds among SME tax debtors. eJournal of Tax Research, IO(2), str. 403-435.

33. Ripstein, A., 2004. Authority i Coercion. Philosophy and Public Affairs, 32(I), str. 2-35. doi: IO.IIII/j.I467-6486.2004.00003.X

34. Silvani, G. i Baer, K., 1997. Designing a Tax Administration Reform Strategy: Experiences and Guidelines. IMF Working Paper, No. 97/30.

35. Slemrod, J., 2004. The economics of corporate tax selfishness. NBER Working Paper, No. 10858. National Bureau of Economic Research.

36. Swistak, A., 2015. West Bank and Gaza. Improving Taxation of SMEs: Design and Compliance Issues. Technical Assistance Report. Washington: IMF (unpublished).

37. Torgler, B., 2007. Tax compliance and tax morale: A theoretical and empirical Analysis. Cheltenham, U.K.: Edward Elgar Publishing Limited.

38. Tullock, G., 1974. Does Punishment Deter Crime? Public Interest, (36), str. IO3-III.

39. Wenzel, M., 2004. The social side of sanctions: personal and social norms as moderators of deterrence. Law and Human Behavior, (28), str. 547-567. doi: I0.1023/B:LAHU.0oooo46433.57588.7I 